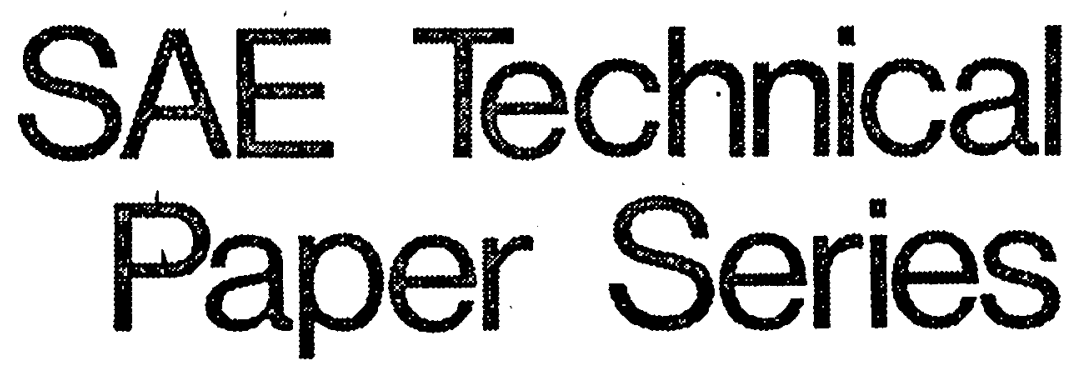

851225

\title{
Transportation Fatalities: A Risk Assessment
}

Paul Hoxie 
The appearance of the code at the bottom of the first page of this paper indicates SAE's consent that copies of the paper may be made for personal or internal use, or for the personal or internal use of specific clients. This consent is given on the condition, however, that the copler pay the stated per article copy fee through the Copyright Clearance Center, Inc., Operations Center, 21 Congress St., Salem, MA 01970 for copying beyond that permitted by Sections 107 or 108 of the U.S. Copyright Law. This consent does not extend to other kinds of copying such as copying for general distribution, for advertising or promotional purposes, for creating new collective works, or for resale.

Papers published prior to 1978 may also be copied at a per paper fee of $\$ 2.50$ under the above stated conditions.

SAE routinely stocks printed papers for a period of three years following date of publication. Direct your orders to SAE Order Department.

To obtain quantity reprint rates, permission to reprint a technical paper or permission to use copyrighted SAE publications in other works, contact the SAE Publications Division.

No part of this publication may be reproduced in any form, in an electronic retrieval system or otherwise, without the prior written permission of the publisher.

ISSN 0148.7191

Copyright 1985 Society of Automotive Engineers, Inc. 


\section{Transportation Fatalities: A Risk Assessment}

\section{ABSTRACT}

This paper assesses the relative fatal1ty risk of transportation modes and submodes for use in publio safety resource allocation. Average annual fatalities for the modes and submodes are compared. Factors which might influence society's valuation of risk are examIned -- victim age, trends in fatalities, and variability of ratalities. Finally, other measures of risk (ratalities per ton-mile, per passenger-mile, and per vehicle) are presented to help judge the acceptability of existing risk levels.

THE PURPOSE OF THIS PAPER is to develop an assessment or transportation ratal1ty risk which is appropriate for use in considering rederal expenditures on transportation sarety. A measure of transport fatallty risk should have two properties: It should measure the probability or relative frequency of a defined event, and the consequences of the event across modes shodld be similarly valued by society. The average number of ratalities per year is one of the best measures of modal transportation ratality risk for use in publio policy analysis. This measure has a roughly comparable measure of the consequences of the event, a death, across modes and measures the expected rrequency of the event. Average fatallties per year measures the extent of the problem and, therefore, 1 better for judging resource allocation than other commonly used measures of risk such as fatalities per passenger mile. Clearly, average ratallties per year does not provide all of the information needed to assess fatality risk, so other measures are also prem sented to complete the assessment of modal transportation fatality risk.

\section{AVERAGE ANNUAL FATALITIES}

Transportation fatalities are largely highway ratal1t1es, as Figure 1 illustrates.
Paul Hoxie

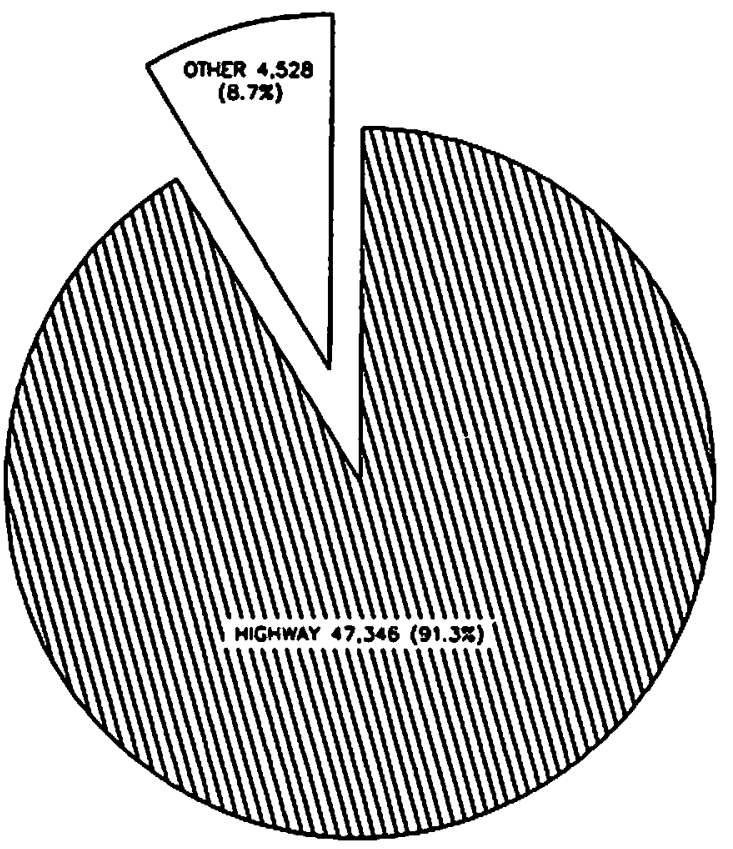

FIGURE 1. TRANSPORT FATALITIES - HIGHWAY AND OTHER (1975-1983) MEAN

During the 1975 to 1983 period over 90 percent of all fatalities were highway fatalities.

The major modal components of non-highway transportation fatalities are shown in Flgure 2. Airway, rallway, and waterway fatalit1es eaoh account for about one-third of the nonh1ghway transportation fatalities.

Figure 3 shows the major submode components of non-highway fatal1ties.

- Almay fatal1ties are mostly general aviation fatal1ties; 


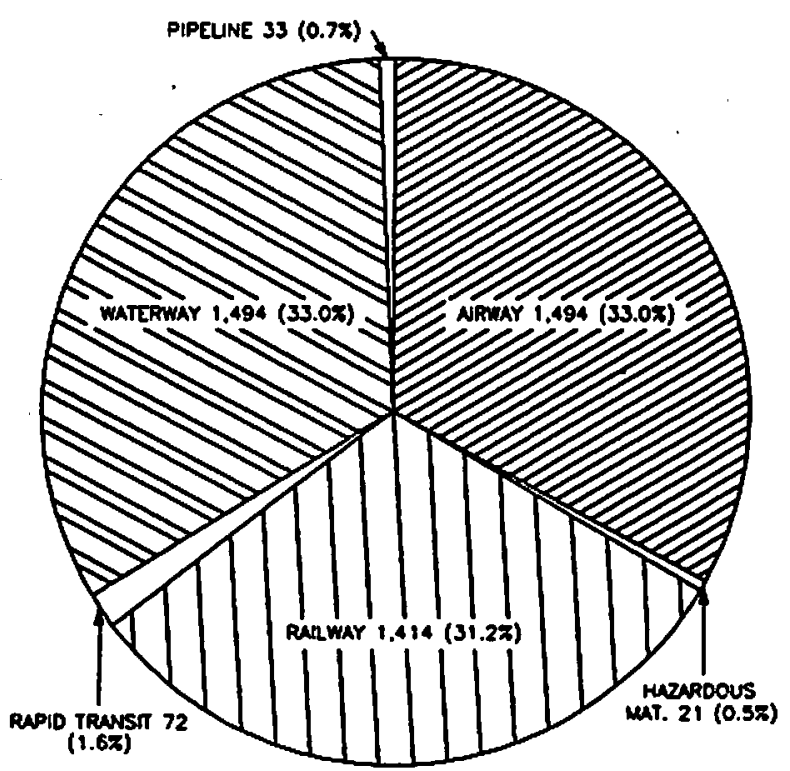

FIGURE 2. COMPONENTS OF NON-HIGHWAY FATALITIES (1975-1983 MEAN)

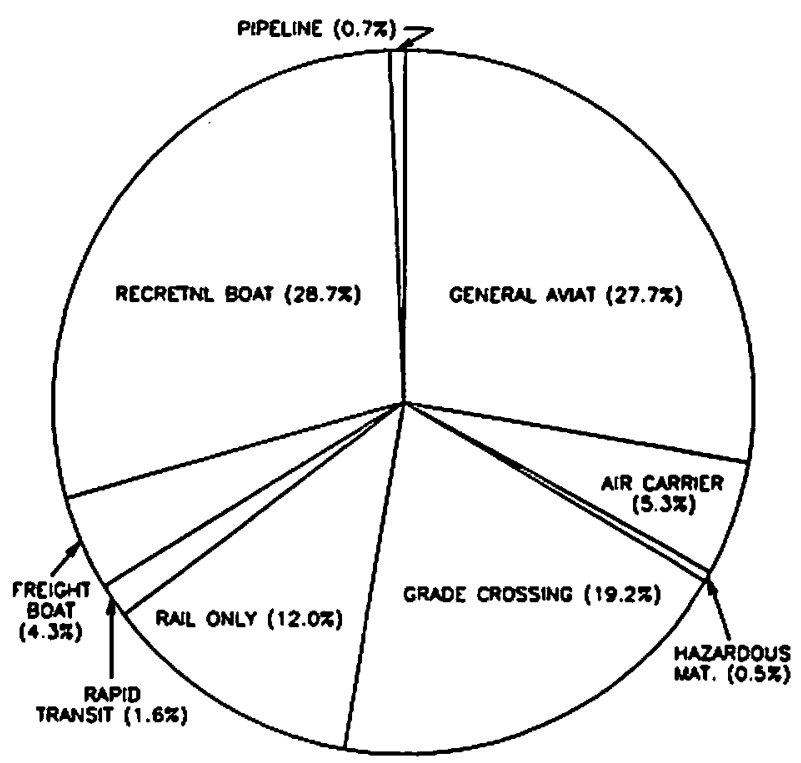

FIGURE 3. COMPONENTS OF NON-HIGHWAY FATALITIES (1975-1983 MEAN)

- Grade crossing accidents, which are counted as both rallway and highway fatalities in Figure 1, represent 60 percent of all rallway fatalit1es; and

- Haterway fatelities are dominated by recreational bosting fatalities.

For each of these three modes, most ratalItIes are occupants of non-commercial vehicles.
(See Prensky et al. (1) for other categor 1zations of submodes for both acoldents and fatal1ties.) P1peline, hazardous materials, and rapld transit account for relatively few fatal1t1es.

A breakdown of highway ratalitieg into occupant fatalities by submodes (see Figure 4) reveals that the commercial vehicles (mediun and heavy trucks and buses) account for less than flve percent of highway occupant fatal1t1es. However, because trucks and buses are heavier than the veh1cles they typlcally hit, the occupant of the other vehicle 19 more ilkely to die. Therefore, commerical vehicles are involved in more fatal accidents than Figure 4 indicates. More than 75 percent of highway occupant fatalitieg are accounted for by the non-comercial vehicle submodes: passenger cars, light trucks and vans, and motorcycles.

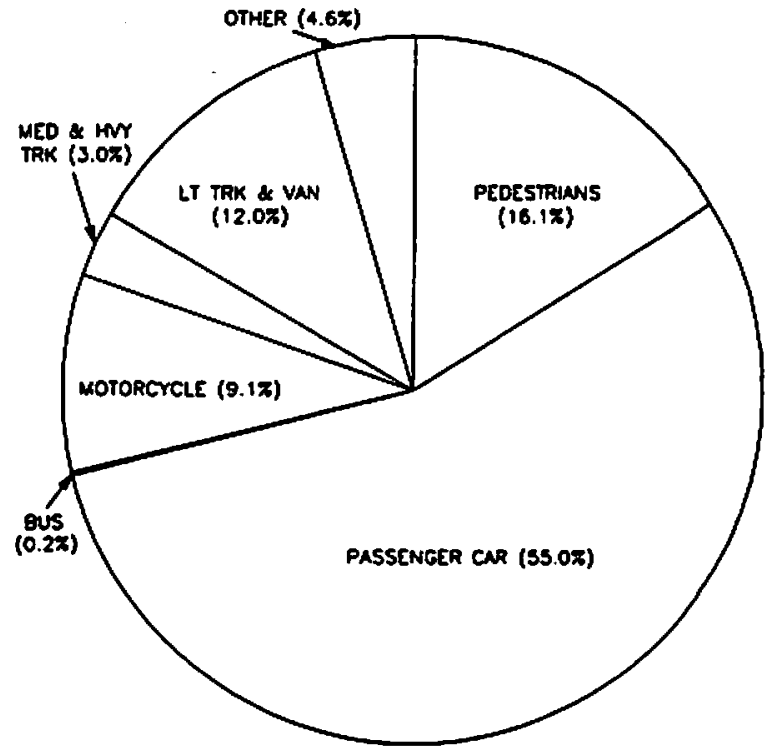

FIGURE 4. COMPONENTS OF HIGHWAY FATALITIES (1975-1983 MEAN)

For perspective on the relative number of fatalities by transport wode, notice that each year about as many people die in motorcyole accidents as in all non-highway acoidents combined.

\section{OTHER ATTRIBUTES OF FATALITY RISK}

Three other ractors are 1mportant to consider in assessing the relative fatality risk of each mode: the age of the victims, the variability of the modal fatality levels, and the recent trends in ratalities. These three factors might suggest that the measure of relative fatality risk presented above ahould be modifled to account for modal differences.

Number in parentheses refer to references listed at the end of the paper. 
VICTIM AGE: In using average annual fata11t1es to compare modal fatal1ty risk, we assume that a death on one mode is equal to a death on another mode. Wh1le this seems like a good assumption, it may not be adequate to capture the economic loss to soclety. Studies of the economia cost of motor vehicle accldents (for example hartunian et al (2) or NHTSA (3)) have found that a very large share of the oost of highway fatalities is the present value of foregone eaminga. Since the present value of foregone earnings depends on the income and age of the viotim, a death on one mode is equal to a death on another mode only if the joint ageInoome distribution of the victims is the same for both modes. Since only the age distribution of the victims is avallable, Figure 5 shows the age distribution of the victims. The major modes are very sinilar. Alrway victims are alightly older than highway, rallway, and waterway victims, but the victims of all modes are dramatically younger than the victims of heart attack-the major killer in the United States. Therefore, compar1sons of fatality rlsk between transportation and heart attack causes should value each transport fatality more than each heart attaok fatality because of the substantial difference in the age (and ruture earnings) of the victims. In contrast, the differenoes in the age distribution of the victins among the transportation modes 19 go slight that no adjustment to the measure of overall rigk 1s necessary based on the age of the victim.

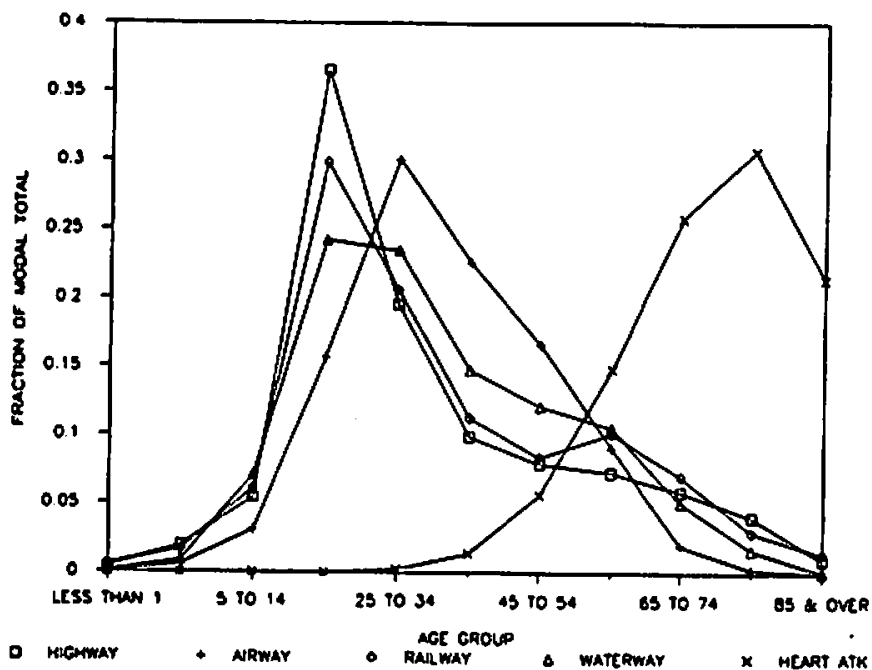

FIGURE 5. AGE DISTRIBUTION OF THE DEAD: FRACTION OF MODAL TOTAL

Sources: Baker et al. (4) and U.S. National Center for Health Stat1ot1cs (5)

VARIABILITY OF FATALITIES: Aocidents where many people die at onoe create an 1mpression of high risk which affects not only the general pub110, but also those in government who allocate safety resources. Whlle few would argue that resources should be allocated based on the worst accident, advocates might argue that certain modes have the potential to be dramatically more dangerous than they currently are and that any reduced vigilance will regult in very substantial increases in annual fatalities. This argument is difficult to evaluate, but one approach is to examine the variability of modal fatalities. High variability may be an indication of the "potential rigk" of a mode. To 1llustrate the variability of each submode, the fatalities for the year with the highest number of fatalities in the 1975 to to 1983 period 13 plotted against the nine-year mean in Figure 6 . If the worst year were equal to the mean, the point would fall on the d1agonal line on the graph. The larger the distance from the line, the higher the varlability of fatalities for the mode. Notice that air carrier, pipeline, and hazardous materials are the three submodes where the worst year varies the wost from the mean. However, even if the worst year were considered rather than the mean for these three submodes, their relative rank among all transportation submodes would not change. Furthermore, the fatalities which result from these modes would still be dwarfed by the mean fatality levels for the highway submodes.

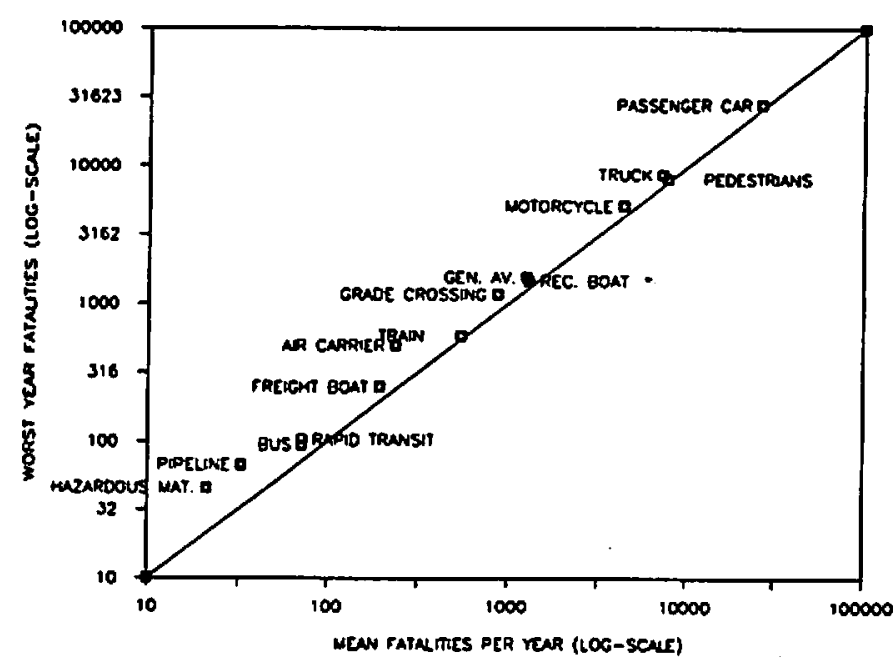

FIGURE 6. VARIABILITY: WORST YEAR VS. MEAN (1975-1983)

RECENT TRENDS: Another 1mportant characteristic of the submode fatality levels which is not captured by the mean 19 the recent trend in fatelities. If the recent trend were toward elther dramatically lower or higher fatality levels, it would suggest that the mean overestimates or underestimates the current expected fatality level. One measure of the recent trend 18 the average annual percentage change in fatalities for the five years since 1978. However, some of this change may be due to random variation. To help Judge the rel1- 
ab1lity of the average annual peroentage change, It is plotted against the probab1lity that the change was due to chance. This probablilty is calculated for each wode from the change for each year during the five years using the Student's $t$ distribution.

As Figure 7 shows, in 1983 all the transportation subwodes had fatality levels that were below the 1978 level. The submodes with the highest percentage declines (alr carrier and hazerdous materials) are not the submodes most likely to have declines which are not due to chance. Grade crossing and passenger car fatalities are much more likely to be declining than alr carrier or hazardous materlal fatal1t1es.

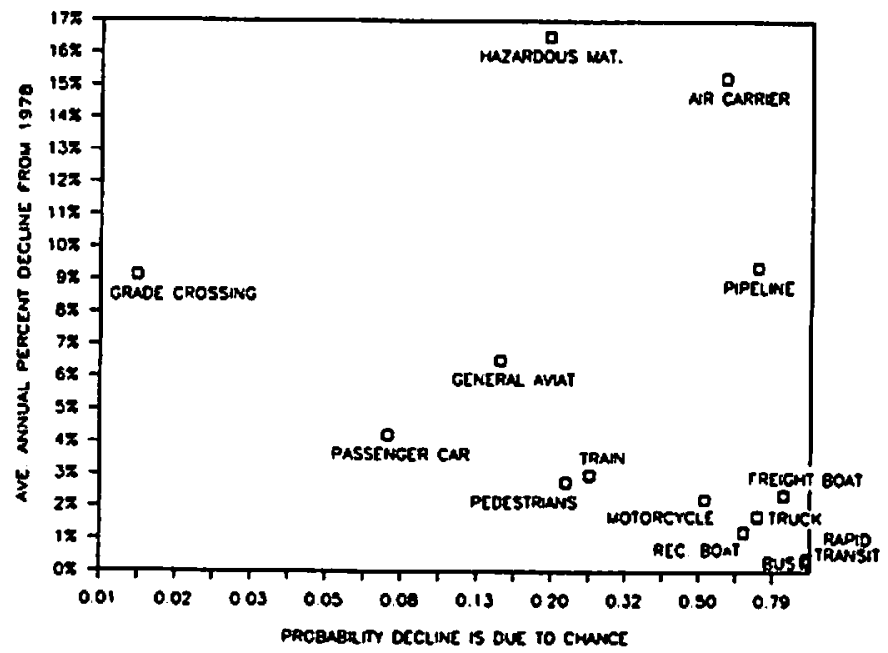

FIGURE 7. FATALITY DECLINES: FIVE YEAR TRENDS (AV.ANNUAL \& DECLINE VS.RELIABILITY)

What can be said about the trend differences among the modes? Grade crossing fatalities are most certainly declining more than the subeodes which are clustered in the bottom right corner of Figure 7, (motorcycle, freight boat, truck, recreational boat, rapid transit, and bus). Are grade crossing fatalIties declining more or less than passenger car fatalities, or more or less than hazardous material fatalities? Even at the falrly permissive confidence level of 80 percent, the grade crossing fatality decline cannot be distingulsed from the passenger car or the general aviation or the hazardous material decline, the submodes w1th the greatest 11kelihood of declining trends. So, without a clear difference among the modes, no adjustment to average annual fatalities to account for d1fferences in modal fatality trends is warranted.

Are these declines in transportation fatalities for all modes likely to continue? Hedlund et al (6) suggests that for highway fatalities the depressed economy was the major factor responsible for the decline, implying that economic recovery would lead to higher highway fatality levels. As Figure 8 indicates, highway fatallty levels for 1984 were higher than 1983 levels and forecasts for 1985 st11l h1gher. These forecests are based on DRI's forecasts (7) of disposable income and TSC's econometric model (8) of the relationsh1p between disposable income and highway fatal1tles. Simliar analyses of the fatality levels for other modes have not been found, possibly because of the low numbers of fatalities and the consequent high relative varlability of the fatal1ty series. However, it seems 11kely that the major mechanisms through which the economy Influences highway fatalities, Income levels Influence the amount of driving and associated fatalities, also act to affect other modal fatality levels. So, the declines in transportation fatalities between 1978 and 1983 should not be expected to continue.

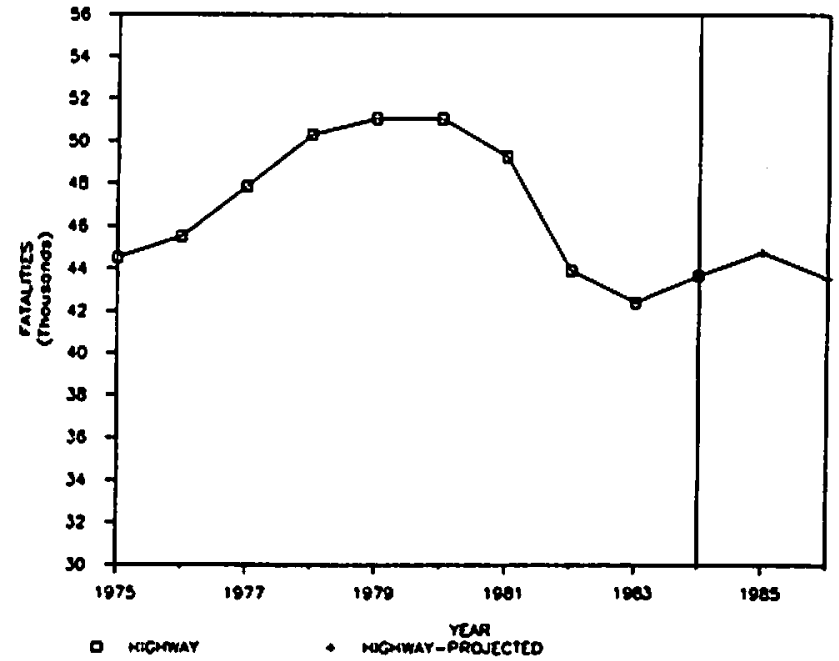

FIGURE 8. HIGHWAY FATALITIES BY YEAR

CONCLUSIONS: The assessment of transportation fatality risk based on average annual fatalities does not need to be modifled based on modal differences in the age distribution of the victims, modal differences in the variab1l1ty of the annual fatality levels; or differences in the trends of modal fatalities. Further, the declines in transportation fatality levels between 1978 and 1983 are not $11 k e l y$ to continue. Instead fatalities are likely to grow because of growth in the econowy.

\section{OTHER MEASURES OF FATALITY RISK}

Average fatalities per year meagures modal transportation fatality risk well for public resource allocation, but fatality risk may also be evaluated in relation to the product: tonmlles for frelght modes, passenger-miles for passenger modes, and vehlcles for personal use modes. These measures, whlch radically change the risk pleture, are useful in judging the acceptability of the risk and controlling for 
the wide difference in the extent of the modal use. These measures are oommonly used to judge year-to-year changes in fatality levels within a mode or submode, but their usefulness in public safety resource allocation 19 imited because they do not measure the magnitude of the fatality problem.

Figure 9 shows fatalities per billion tonmiles for the wajor freight modes. Medium and heavy truck occupant fatality rates are the highest. The rate would be even higher if fatal accident involvements were measured that 13 if all fatalities in accidents involving medium and heavy truck were counted rather than only the truck occupants. If grade crossing fatalities are elininated from the rallway fatal1ty rate (resulting in "Ra1l Only"), the truck and rall measures would be oloser to measuring the same thing (oocupant fatalities) since the highway vehicle occupant usually dies in fatal grade crossing accidents.

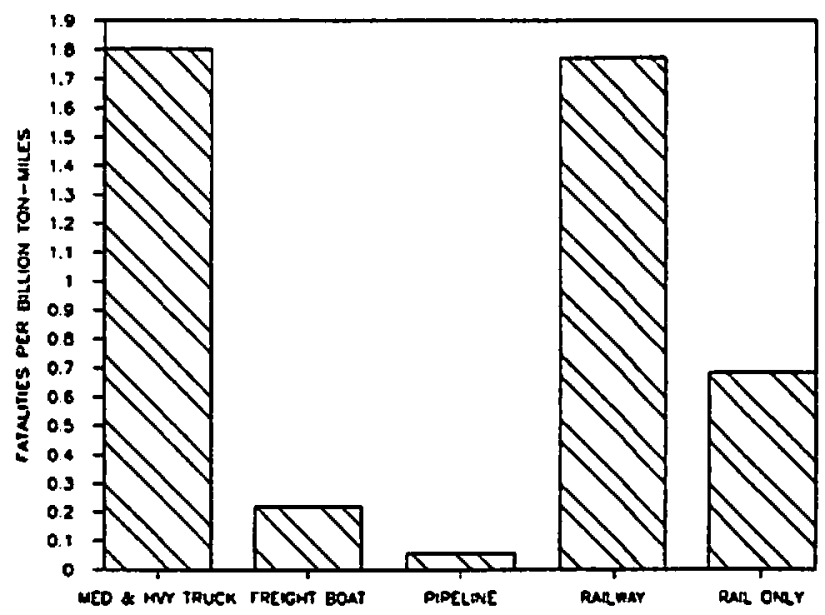

FIGURE 9. MEAN FACILITIES PER BILLION TONMILES ( (1975 - 1983) MEAN, TONMILES (1982))

Fatalities per thougand vehicles for the major personal use modes are shown in Figure 10. (A log-scale is used so that the modal differences are more eas1ly compared to those In Figure 11 which w11l be considered next). General aviation has the highest number of ratalities per veh1cle by a factor of about ten. ThIs 13 at least partly because alrplanes are used more intensively (1.e. more passengerwiles per year) than other vehtcles. Motorcycles have about three times the number of fatalities per vehtcle as passenger cars while recreational boats have about half as many fatalities per vehicle as passenger cars.

Fatalities per passenger-mile reveal a different picture. Figure 11 shows that, when fatalities per billion passenger miles are oonsidered, motorcycles are about 25 times as dangerous as passenger cars and general aviation

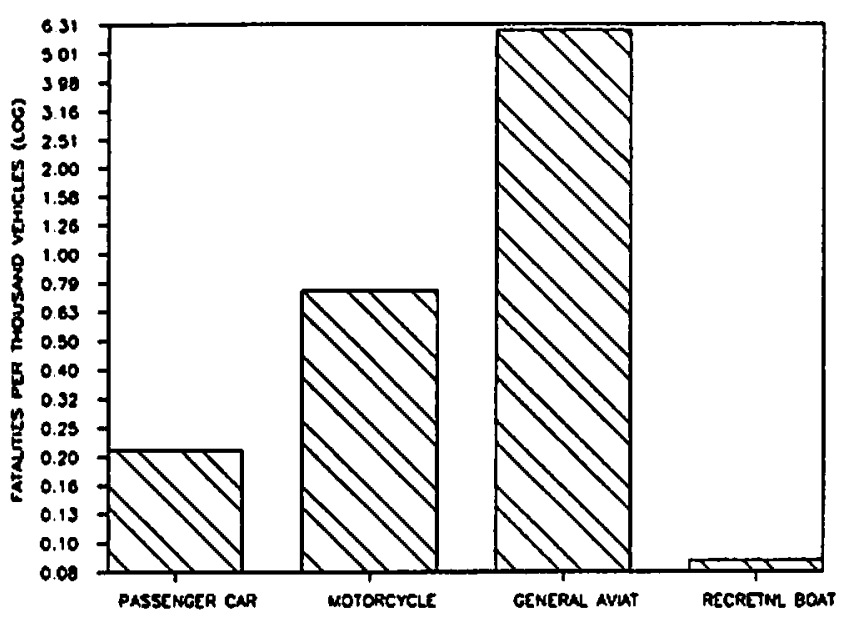

FIGURE 10. MEAN FATALITIES PER VEHICLE ((1975 - 1983) MEAN, VEHICLES (1982))

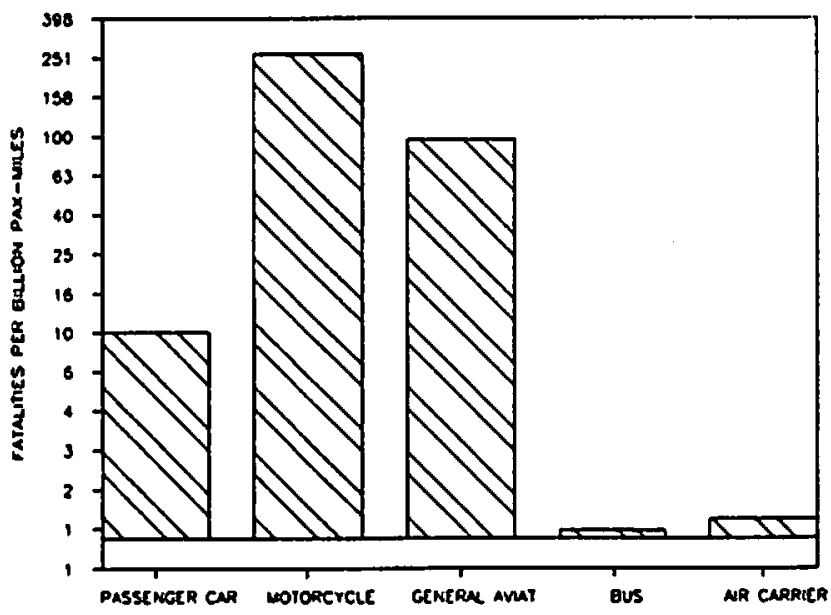

FIGURE 11. MEAN FATALITIES PER PAX-MILE ((1975 to 1983) MEAN, PAX-MILES (1982))

13 about ten times as dangerous. The two common carrier modes, bus and alr carrier, are dramatically gafer than the pergonal use modes. This makes sense since the acceptability of risk must be in part determined by the degree of control the risk-taker has over the risk. It could be argued that common carrier modes should be as safe as the safest driver groups, so that no group would be taking more risk using a comon carrier than they would take driving themselves. How much safer than passenger car travel should bus and alr travel be? This is a matter of judgment but for perspective, Mengert et al. (9) classifled involvements in fatal acoidents and vehicle miles travelled into 576 categories based on driver age and sex; veh1ole age and welght; t1me of day, day of week, and season; land use; and number of ocoupants in the vehicle. They found that a ratio of about 200 to 1 exists between fatal accident involvement rates per passenger car-m1le of the safest and the most dangerous categorles. Should the common carrier modes 
have fatality rates per wlle that are $1 / 100$ th of the passenger car rates as th1s ratio suggests, or should groups which are not quite as gafe be chosen as the standard? Much more information on the distribution of passenger car risk as well as public attitudes toward risk would be needed in order to make this judgment.

\section{SUMARARY}

H1ghway acoldents account for about 90 percent of all transportation ratalities. As Figure 12 11lustrates, passenger car occupant ratalities account for 50 percent of all transportation fatalities, followed by pedestrians ( 15 percent), 11ght trucks and vans (11 percent), and motorcycles ( 8 percent). Almay, dominated by general aviation; rallway, dominated by grade crossing, and watemay, dominated by recreational boating; comprise equal thirds of the 9 percent of transportation fatallties which are not highway. Examination of the age distribution of the victims, the variability of the fatalities and the recent trend in fatalities by mode suggest that average annual fatallties alone provides a reasonable representation of societal ratality risk for the transportation modes.

Finally, desplte slgniflcant declines in transportation fatalities, particularly highway ratalites, between 1978 and 1983, fatal1ty levels are likely to grow again with growth in the econowy, dramatizing the need for federal support of transportation safety.

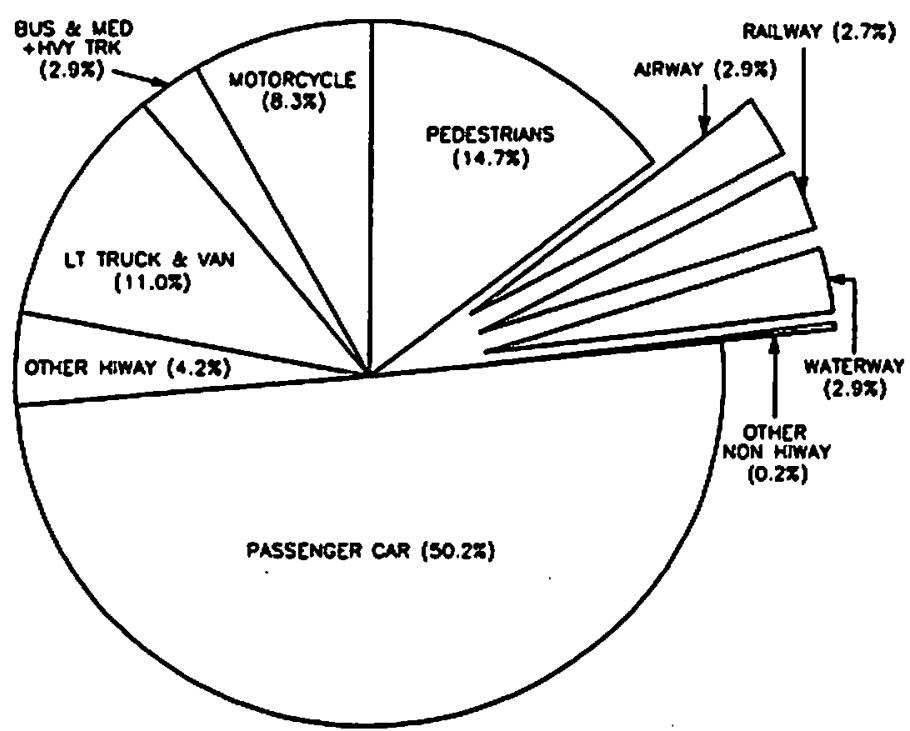

FIGURE 12. TRAMSPOATATION FATALITIES ((1975 to 1983) MEAN)

\section{ACKNOWLEDGEMENT}

Many people made suggestions which Improved this paper: Thomas Harvey, Donald Sussoan; Peter Mengert, Simon Prensky, David Skinner, and Carol Gurvitz of. TSC, and Michael Finkelstein and James Hedlund of NHTSA. The vlews expressed In the paper are the author's and not those of TSC or any part or DOT.

\section{REFERENCES}

1. Prensky, S.; D. Hoodman; J. Bellanton1; $M$. NeInhaus; E. Roberts; D. Splller; The Status of Iransportation Safety

Transportation Systems Center Report $\$$ SS223-05-64, May 1982.

2. Hartunian, H.S; C.N. Smart, and M.S. Thompson, The Incidence and Economic Costs or Major Health Impairments, Lexington Books, 1981.

3. (U.S.) National Highway Traffic Safety Adoinistration, The Economic Cost to Society of Motor Vehicle Accidents, NHTSA Report No. DOT-HS 806 342, January 1983.

4. Baker, S.P.; B. O'Ne111, R.S. Karpf, The Injury Pact Book, Lexington Books, 1984 .

5. (U.S.) National Center for Health Statistics, Hyattsville, Maryland, Vital Statist1cs Mortality Data Cause of Death Summary, 1979, NTIS \#PB83-132365, December 1982.

6. Hedlund, J.; R. Amold; E. Cerrelli; S. Partyka; P. Hoxie; D. Skinner, "An Assessment of the 1982 Iraffic Fatality Decrease" Accident Analysis and Prevention, Vol 16, No. 4, pp. 247-261, 1984.

7. Data Resources, Inc. Review of the U.S. Economy, January 1985.

8. Hoxie, P. and D. Skinner, A Statistical Analysis of the Soc10-Economic Influences on Three Groups of High-Risk Fatalities, soon to be published Transportation Systems Center report.

9. Mengert, P.; R. Bair; R. D1Gregor10; P. Hoxie; R. Mumford, Development of Multivariate Fatal Accident Involvement Rates for 1977; Transportation Systems Center Report, March 1984.

10. Saccocc1o, M. Transportation Safety Information Report: 1983 Annual Report. Transportation Systems Center Report DDTTSC-RSPA-84-2, Apr11 1984.

11. Spauld1ng, P. National Trangportation Stat1st1cs: Annual Report; Transportation Systems Center Report DDOT-TSC-RSPA-84-3, August 1984. 
AFF'END I $X$

\begin{tabular}{|c|c|c|c|c|c|c|c|}
\hline MODE/SUEMODE & $\begin{array}{l}\text { MEAN } \\
\text { ATALITIES } \\
75-83\end{array}$ & $\begin{array}{l}\text { WOFST } \\
\text { YEAR }\end{array}$ & $\begin{array}{l}\text { AVE DECL. INE } \\
\text { FER YEAR } \\
1978-83\end{array}$ & $\begin{array}{l}\text { STD DEV } \\
\text { OF THE } 5 \text { YR } \\
\text { DECLINE }\end{array}$ & $\begin{array}{r}\text { VEHICLES } \\
1982 \\
(10 * * 3)\end{array}$ & $\begin{array}{r}\text { FAX-MILES } \\
1982 \\
(10 * * 9)\end{array}$ & $\begin{array}{r}\text { TON-MILES } \\
1982 \\
(10 * * 9)\end{array}$ \\
\hline HIGHWAY & 47345.9 & 51093 & & & 165157.9 & & \\
\hline FASSENGER CAR & 26052.0 & 28153 & 1189.4 & 492.89 & 123697.9 & 2607.9 & \\
\hline FEDESTRIANS & 7613.2 & 8096 & 216.0 & 148.02 & & & \\
\hline BUS & 72.0 & 95 & 0.2 & 6.76 & & 74.2 & \\
\hline LT TFK \& VAN & 5693.1 & 6539 & 51.0 & 130.33 & & & \\
\hline MED \& HVY TRK & 1429.0 & 2209 & 75.6 & 238.32 & & & 792.7 \\
\hline MOTOF'CYCLE & 4295.1 & 5144 & 102.4 & 144.89 & 5743.5 & 16.5 & \\
\hline OTHEF & 2191.4 & 2493 & & & & & \\
\hline AIRWAY & 1494.3 & 1921 & & & & & \\
\hline GENERAL AVIAT & 1255.9 & 1558 & 101.8 & 56.40 & 209.8 & 13.1 & \\
\hline AIR CARFIER & 238.4 & 494 & 55.4 & 93.05 & & 213.6 & \\
\hline FAILWAY & 1413.7 & 1684 & & & & & 797.8 \\
\hline GRADE CRIOSSING & 869.9 & 1174 & 97.2 & 24.11 & & & \\
\hline TRAIN & 543.8 & 584 & 17.4 & 13.02 & & & \\
\hline $\begin{array}{l}\text { RAFTD TRANSTI } \\
\text { WATEFIWAY }\end{array}$ & $\begin{array}{r}72.0 \\
1494.3\end{array}$ & $\begin{array}{r}103 \\
1709\end{array}$ & 0.2 & 10.36 & & & \\
\hline RECRETNL BOAT & 1299.3 & 1466 & 16.0 & 33.79 & 14900 & & \\
\hline FREIGHT EOAT & 195.0 & 248 & 4.4 & 21.92 & & & 886.5 \\
\hline FIFELINE & 32.9 & 68 & 3.2 & 8.28 & & & 571 \\
\hline HAZARDOUS MAT. & 21.1 & 46 & 7.6 & 4.89 & & & \\
\hline SDURCES: SACCOCIO & (10) AND & SPAULDING & $(11)$ & & & & \\
\hline
\end{tabular}


This paper is subject to revision. Statements and opinions advanced in papers or discussion are the author's and are his responability, not SAE's; however, the paper has been edited by SAE for uniform styling and format. Discusaton will be printed with the paper if it is publiahed in SAE Transactions. For permission to publish this paper in full or in part, contact the SAE Publieations Dtrision.
Persons withing to submit papers to be considered for presentation or publication through SAE should send the manuseript ot a 300 word abstract of a proposed manuscript to: Secretary, Enginearing Acthity Board, SAE.

12 page booklet
Printed in U.S.A. 